\title{
PENGEMBANGAN PERMAINAN KINESTETIK UNTUK SISWA SEKOLAH DASAR
}

\author{
Frendy Aru Fantiro, M. Pd \\ Universitas Muhammadiyah Malang \\ E-mail: frendy_aru@umm.ac.id
}

\begin{abstract}
Based on observations and interviews with PJOK teachers SD Negeri Sitirejo 2 Wagir Kab. Malang concluded that there were less than the maximum learning models based on motor physical games, especially the game of kinesthetic intelligence which requires elementary school students to move actively. This study aims to develop the game kinesthetic 2 of public elementary school students 2 Sitirejo Wagir Malang especially class 4. From the results of the evaluation of small group trials using 4 experts. $77.58 \%$ for media experts, $88.09 \%$ for motorists, $78.95 \%$ for game experts and $90.90 \%$ for subject learning experts. in the large group test using 30 students obtained a percentage of $91.19 \%$, based on the results of the game model kinesthetic intelligence of public elementary school students 2 Sitirejo poor Wagir can be used in the learning process
\end{abstract}

Keywords: Development, Games, Kinesthetic

\begin{abstract}
Abstrak: Berdasarkan hasil observasi dan wawancara dengan guru PJOK SD Negeri Sitirejo 2 Wagir Kab. Malang disimpulkan Kurang maksimalnya model-model pembelajaran pjok yang berbasis permainan fisik motorik khususnya permainan kecerdasan kinestetik yang mengharuskan siswa sekolah dasar aktif bergerak. Penelitian ini bertujuan mengembangkan permainan kinestetik siswa SD negeri 2 Sitirejo Wagir malang khususnya kelas 4. Dari hasil evaluasi uji coba kelompok kecil dengan menggunakan 4 ahli. 77,58\% untuk ahli media, 88,09\% untuk ahli motorik, 78,95\% untuk ahli permainan dan 90,90\% untuk ahli pembelajaran penjas. pada uji kelompok besar dengan menggunakan 30 siswa diperoleh persentase $91,19 \%$, berdasarkan hasil tersebut model permainan kecerdasan kinestetik siswa SD negeri 2 Sitirejo Wagir malang dapat digunakan dalam proses pembelajaran
\end{abstract}

Kata Kunci: Pengembangan, Permainan, Kinestetik

\section{PENDAHULUAN}

Setiap anak mempunyai tingkat kecerdasan dan cara belajar yang berbeda. Cara anak belajar adalah dengan bermain, karena melalui bermain anak mampu mengoptimalkan kemampuannya dari aspek bahasa, sosial, kognitif, fisik dan moralnya. (Mutiah,2010:181).

Pengalaman yang dialami anak pada usia dini akan berpengaruh kuat terhadap kehidupan selanjutnya (mutiah,2010:182). Pengalaman tersebut akan bertahan lama. Bahkan tidak dapat terhapuskan, walaupun bisa hanya tertutupi. Bila suatu saat ada stimulasi yang memancing pengalaman hidup yang pernah dialami maka efek tersebut akan muncul kembali walau dalam bentuk yang berbeda.

Masa usia sekolah dasar sebagai mesa kanak-kanak akhir yang berlangsung dari usia enam tahun hingga kira-kira usia sebelas tahun atau dua belas tahun. Karakteristik utama siswa sekolah dasar adalah mereka menampilkan perbedaan-perbedaan individual dalam banyak segi dan bidang, di antaranya, perbedaan dalam intelegensi, kemampuan dalam kognitif dan bahasa, perkembangan kepribadian dan perkembangan fisik anak.

Menurut Erikson perkembangan psikososial pada usia enam sampai pubertas, anak mulai memasuki dunia pengetahuan dan dunia kerja yang luas. 
Peristiwa penting pada tahap ini anak mulai masuk sekolah, mulai dihadapkan dengan tekhnologi masyarakat, di samping itu proses belajar mereka tidak hanya terjadi di sekolah.

Sedang menurut Thornburg (1982) anak sekolah dasar merupakan individu yang sedang berkembang, barang kali tidak perlu lagi diragukan keberaniannya. Setiap anak sekolah dasar sedang berada dalam perubahan fisik maupun mental mengarah yang lebih baik. Tingkah laku mereka dalam menghadapi lingkungan sosial maupun non sosial meningkat. Anak kelas empat, memilki kemampuan tenggang rasa dan kerja sama yang lebih tinggi, bahkan ada di antara mereka yang menampakan tingkah laku mendekati tingkah laku anak remaja permulaan.

Menurut Piaget ada lima faktor yang menunjang perkembangan intelektual yaitu : kedewasaan (maturation), pengalaman fisik (physical experience), penyalaman logika matematika (logical mathematical experience), transmisi sosial (social transmission), dan proses keseimbangan (equilibrium) atau proses pengaturan sendiri (self-regulation) Erikson mengatakan bahwa anak usia sekolah dasar tertarik terhadap pencapaian hasil belajar.

Mereka mengembangkan rasa percaya dirinya terhadap kemampuan dan pencapaian yang baik dan relevan. Meskipun anak-anak membutuhkan keseimbangan antara perasaan dan kemampuan dengan kenyataan yang dapat mereka raih, namun perasaan akan kegagalan atau ketidakcakapan dapat memaksa mereka berperasaan negatif terhadap dirinya sendiri, sehingga menghambat mereka dalam belajar. Piaget mengidentifikasikan tahapan perkembangan intelektual yang dilalui anak yaitu : (a) tahap sensorik motor usia 0-2 tahun, (b) tahap operasional usia 2-6 tahun, (c) tahap opersional kongkrit usia 7-11 atau 12 tahun, (d) tahap operasional formal usia 11 atau 12 tahun ke atas.
Kebugaran jasmani mempunyai arti penting dalam proses pembelajaran pendidikan jasmani siswa sekolah dasar, antara lain dapat meningkatkan fungsi organ tubuh, sosial emosional, sportifitas,dan semangat berkompetisi. Dengan memiliki kebugaran jasmani yang tinggi, siswa mampu melakukan aktivitas sehari-hari dengan waktu yang lebih lama. Seperti yang di ungkapkan Suharjana (2008:5) bahwa: "Kebugaran jasmani pada hakikatnya adalan kemampuan tubuh seseorang untuk melakukan aktivitas sehari-hari sesuai pekerjaan tanpa timbul kelelahan berlebihan, sehingga masih dapa menikmati waktu luang".

Kecerdasan kinestetik, yakni kemampuan untuk menggunakan seluruh tubuhnya untuk mengekspresikan ide-ide dan perasaan-perasaan atau menggunakan tangan- tangan untuk menghasilkan dan mentransformasikan sesuatu. Kecerdasan ini mencakup keahliankeahlian fisik khusus seperti koordinasi, keseimbangan, ketangkasan, kekuatan, kelenturan dan kecepatan. (Howard Gardner 2001:3).

Kecerdasan kinestetik adalah kemampuan menyelaraskan pikiran dengan badan sehinnga apa yang dikatakan oleh pikiran akan tertuang dalam bentuk gerakan-gerakan badan yang indah, kreatif, dan mempunyai makna. Definisi ini merujuk pada tulisan yang mengatakan bahwa "...Sebuah keselarasan antara pikiran dan tubuh, dimana pikiran dilatih untuk memanfaatkan tubuh sebagaimana mestinya dan tubuh dilatih untuk dapat merespon ekspresi kekuatan dari pikiran" (Linda C, Bruce C dan Dee D, 2002). Anak-anak dengan kecerdasan kinestetik memiliki tipe belajar yang mengandalkan tangan atau tubuhnya atau disebut dengan cara belajar kinestetik. Mereka merespon sesuatu dengan baik pada komunikasi nonverbal. Mereka juga cepat belajar gesture, yakni menyampaikan sesuatu 
dengan bagian tubuhnya, terutama tangan.

Kecerdasan kinestetik berhubungan erat dengan motorik. Motorik merupakan perkembangn pengendalian gerakan tubuh melalui kegiatan yang terkoordinir antara susunan saraf, otot, otak, dan spinal cord. Perkembangan motorik meliputi motorik kasar motorik halus. Motorik kasar adalah gerakan tubuh yang menggunakan otot-otot besar atau sebagian besar atau seluruh anggota tubuh yang dipengaruhi oleh kematangan anak itu sendiri. Sedangkan motorik halus adalah gerakan yang menggunakan otototot halus atau sebagian anggota tubuh tertentu yang dipengaruhi oleh kesempatn untuk belajar dan berlatih misalnya, kemampuan memindahkan benda dari tangan, mencoret-coret menyusun balok, menggunting, menulis, dan sebagainya.

Berdasarkan observasi dan wawancara yang dilakukan peneliti di SD Negeri 2 Sitirejo Wagir Kab. Malang, guru PJOK merasa sangat memerlukan pengembangan-pengembangan model permainan. Jadi, bisa di simpulkan bahwa di butuhkannya variasi-variasi model permainan yang di peruntukkan siswa sekolah dasar yang bertujuan untuk meningkatkan keterampilan gerak siswa, maka dari itu peneliti melakukan penelitian yang berjudul "Permainan Kinestetik Siswa Sekolah Dasar".

\section{METODE}

Peneliti menggunakan sepuluh langkah dari Borg \& Gall (1983:774-775). Adapun bentuk dari metode pengembangan permainan kinestetik siswa sekolah dasar adalah sebagai berikut: (a) Penelitian dan pengumpulan data dalam penelitian awal atau analisis kebutuhan (need assessment) dengan cara menyebarkan angket dan observasi (wawancara) kepada guru PJOK SDNegeri 2 Sitirejo Wagir Malang, (b) Perencanaan (pendefinisian keterampilan penentuan urutan pengajaran), (c) Pengembangan draf produk berupa rancangan produk, (d) Evaluasi ahli (dilakukan oleh beberapa ahli), (e) Uji coba lapangan awal (dilakukan pada siswa kelas 4 dengan menggunakan 8 subjek yang diambil secara acak), (f) Merevisi hasil uji coba (sesuai dengan saran-saran hasil uji coba lapangan permulaan), (g) Uji coba lapangan utama (dilakukan pada siswa kelas 4 dengan menggunakan 30 subjek yang diambil secara acak), (h) Penyempurnaan hasil uji coba lapangan utama (revisi produk berdasarkan saran-saran dari hasil uji coba lapangan utama), (i) uji efektifitas model (dilakukan pada siswa kelas 4 dengan menggunakan 30 subjek yang diambil secara acak).

\section{HASIL DAN PEMBAHASAN}

Berdasarkan data hasil analisis kebutuhan dengan persentase sebanyak 90\% guru PJOk SD negeri 2 Sitirejo Wagir. belum maksimalnya pembelajaran penjas yang dimodifikasi dalam bentuk permainan. serta diperlukannya model permainan yang bertujuan meningkatkan gerak kinestetik siswa sekolah dasar.

\section{Analisis Data Evaluasi Ahli Media}

Berdasarkan hasil analisis yang

telah dilakukan terhadap tanggapan/penilaian dari ahli media, hasilnya adalah $\mathbf{7 7 , 5 8 \%}$, dari kriteria yang ditentukan dan dapat dikatakan bahwa Pengembangan Permainan Kinestetik Siswa Sekolah Dasar ini memenuhi kriteria CUKUP VALID (60\%-79\%) sehingga dapat digunakan dan dipraktekkan pada uji coba lapangan/ kelompok besar.

\section{Analisis Data Evaluasi Ahli Motorik dan pendidikan jasmani}

Berdasarkan hasil analisis yang telah dilakukan terhadap tanggapan/penilaian dari ahli motorik dan penjas, hasilnya adalah $\mathbf{8 8 . 0 9 \%}$, dari kriteria yang ditentukan dan dapat dikatakan bahwa Pengembangan 
Permainan Kinestetik Siswa Sekolah Dasar ini memenuhi kriteria VALID (80\%-100\%) sehingga dapat digunakan dan dipraktekkan pada uji coba lapangan/ kelompok besar.

\section{Analisis data Evaluasi Ahli Permainan} Berdasarkan hasil analisis yang telah dilakukan terhadap tanggapan/penilaian dari ahli permainan, hasilnya adalah $78,95 \%$, dari kriteria yang ditentukan dan dapat dikatakan bahwa Pengembangan Permainan Kinestetik Siswa Sekolah dasar ini memenuhi kriteria CUKUP VALID (60\%-79\%) sehingga dapat digunakan dan dipraktekkan pada uji coba lapangan/ kelompok besar.

\section{Analisis data Pada Uji Coba kelompok Besar}

Berdasarkan hasil uji coba kelompok besar yang telah dilakukan hasilnya adalah 91,19\%, dari kriteria yang ditentukan dan dapat dikatakan bahwa Pengembangan Permainan Kinestetik Siswa Sekolah dasar ini memenuhi kriteria VALID $\mathbf{( 8 0 \%}$ 100\%) sehingga dapat digunakan dan dipraktekkan dalam proses pembelajaran.

\section{Data Tes Kecerdasan Kinestetik}

Teknik analisis uji-t amatan ulangan digunakan untuk menghitung perbedaan dua mean untuk sampel yang berhubungan atau sampel tak mandiri (dependent sample). Sedangkan dalam penelitian ini yang diuji adalah suatu perlakuan (treatment) eksperimen permainan kecerdasan kinestetik yang dikenakan terhadap satu kelompok obyek penelitian yaitu siswa sekolah dasar yang berjumlah 30 siswa dan dipilih secara acak. Sebelum dan sesudah perlakuan dilakukan pengukuran, selanjutnya antara dua data pengukuran tersebut dianalisis dengan uji-t. dari hasil analisis dapat diketahui perbedaan antara dua mean tes awal dan tes akhir. Dengan kata lain dapat diketahui efektivitas perlakuan eksperimen.

Berdasarkan hasil penelitian uji efektivitas, dapat disimpulkan hasil penelitian uji signifikasi $\mathrm{t}$ hitung= 33,953>t tabel 5\% 2,045 dengan derajat kebebasan 30-1=29. Karena thitung lebih besar daripada t tabel maka hipotesis nihil ditolak. Kesimpulannnya ada perbedaan yang signifikan antara tes awal dan tes akhir. Dengan kata lain permainan kinestetik memiliki efektivitas yang baik untuk meningkatkan kecerdasan kinestetik siswa sekolah dasar.

\section{KESIMPULAN}

\begin{tabular}{llr}
\multicolumn{2}{c}{ Berdasarkan } & \multicolumn{2}{c}{ produk yang } \\
dikembangkan & dalam kenyataanya \\
membutuhkan & pengkajian ulang
\end{tabular} keberadaanya, karena setelah melalui proses penelitian terdapat beberapa hal yang perlu untuk dilakukan perbaikan. Produk Pengembangan Model Permainan Kecerdasan Kinestetik Siswa Sekolah dasar memiliki kelebihan-kelebihan sebagai salah satu alternatif yang dapat dimanfaatkan dalam proses pembelajaran fisik motorik khususnya kecerdasan kinestetik.

Produk yang dikembangkan adalah model permainan kecerdasan kinestetik siswa taman kanak-kanak. Pengembangan ini berisi 5 model permainan yang bervariasi dengan tujuan meningkatkan kecerdasan kinestetik siswa sekolah dasar, model permainan dapat dilakukan dengan mudah sehingga dapat meningkatkan ketertarikan siswa dalam proses pembelajaran.

Pembuatan Produk Pengembangan Kecerdasan Kinestetik Siswa Sekolah Dasar Negeri 2 Sitirejo Wagir Malang ini tentu melalui proses sehingga memungkinkan adanya kesalahan dan kekurangan. Maka dari itu produk yang dikembangkan mulai dari rancangan produk hingga produk ini terselesaikan masih memerlukan beberapa revisi untuk mendapatkan produk yang maksimal. Sebagai upaya memaksimalkan produk 
yang dikembangkan dalam pembuatan produk ini memerlukan

\section{SARAN}

Dalam mengembangkan penelitian ini ke arah lebih lanjut, peneliti mempunyai beberapa saran, sebagai berikut:

1. Untuk model yang digunakan pada produk sebaiknya dipilih siswa yang memiliki kemampuan motorik lebih bagus, agar pembelajaran lebih sempurna.

2. Hasil pengembangan permainan kinestetik ini dapat disebarluaskan ke seluruh.

3. Perlu adanya pembuatan norma kecerdasan kinestetik, hal ini penting agar para guru dapat secara periodik melakukan kecerdasan kinestetik terhadap siswa. Sehingga para guru dapat mengetahui perkembangan motorik siswanya.

\section{DAFTAR PUSTAKA}

Borg W.R, and Gall, MD. 1983. Educational Research: An Introduction. $4^{\text {th }}$ ed. London: Longman Media.

Depdiknas.2007. Konsep Pengembangan Kurikulum Paud Formal. Pusat Kurikulum Balai Penelitian dan Pengembangan.

Dwiyogo, W.D.2010. Dimensi Teknologi Pembelajaran Pendidikan Jasmani dan Olahraga. Malang: Wineka Media.

Faruq, Muhyi,M. 2008. 60 permainan kecerdasan kinestetik indors. Jakarta: Grasindo

Furgon, M. 2006. Mendidik Anak Untuk Bermain. Surakarta: Program Studi D-2 Pendidikan Jasmani

Gardner, Howard. 2004. Multiple Intelligences Best Ideas From Research And Practice. Boston: Pearson Education, Inc.

Hariyanto, Eko. 2011. Pengembangan Pembelajaran Pendidikan Jasmani Dengan Musik Bagi Anak Autis. Jakarta : UNJ
Hartati, Sofia. 2005. Perkembangan Belajar pada Anak Usia Dini. Jakarta : Departemen Pendidikan Nasional.

Hurlock, Elizabeth B (1991) . Perkembangan Anak. Jilid. Terjemahan Meitasari Tjandrasa, Muslichah Zarkasih, dan Agus Drma (Jakarta : Erlangga)

Joyce, Bruce, et al., Model of Teaching. Boston: Allyn and Bacon, 1996.

Kartono, kartini. 2007. Psikologi Anak (Psikologi Perkembangan). Bandung :Mandar maju.

Mutiah, Diana. 2010. Psikologi Bermain Anak Usia Dini. Jakarta: Kencana.

Mutohir, Toho Cholik. Gagasangagasan tentang Pendidikan Jasmani dan Olahraga. Surabaya: Unesa University Press, 2002 